however, one of a chain of coal-fields which will, in my opinion, ultimately be proved to extend under the newer rocks between Dover and Somerset, along the line of the North Downs, in long narrow east and west troughs. It is probably a continuation beneath the Straits of Dover of the coal-measures struck at Calais (see Fig. 2).

The further question as to the value of these fields may be answered by the amount of coal in the fields which are now being worked in Westphalia, Belgium, France, and Somersetshire. The Westphalian coal-field contains 294 feet of workable coal, distributed in II7 seams; that of Mons, 250 feet, in r ro seams; and that of Somerset, 98 feet, in 55 seams. The North French coal-field in I 887 yielded $7,119,633$ tons, and gave employment at the pits to 29,000 men, and is rapidly increasing its output.

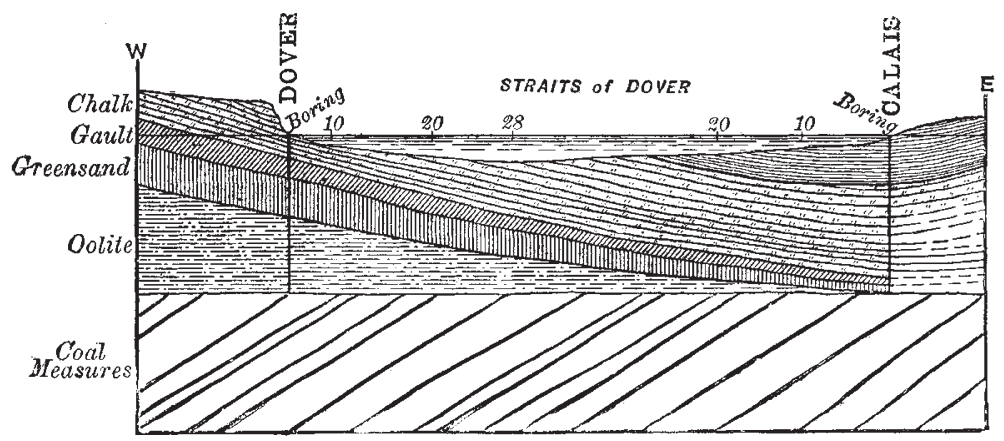

FIG. 2,-Probable Range of Coal-measures between Dover and Calais.

It may be inferred that the buried coal-fields which await the explorer in the North Downs are in all prob. ability not inferior to these. Godwin-Austen, in his memorable paper before the Geological Society, in 1855 , said that if one of these buried fields were once struck in South-Eastern England, their exploration would be an easy matter. It has been struck at Dover, and the necessary base is laid down for further discoveries, which in all probability will restore to South-Eastern England the manufactures which have long since fled away to the coal districts of the west and north, and which will put off by many years the evil day when the energy stored up in the shape of coal in these islands shall have been spent.

\section{RECENT ADDITIONS TO THE LITERATURE OF INSULAR FLORAS.}

THE LACCADIVES.

THESE small islands, fourteen in number, are situated between $10^{\circ}$ and $14^{\circ} \mathrm{N}$. lat., and at 120 to 180 miles from the Malabar coast of India. They are of coral formation, almost without exception portions of atoll rings, and nowhere elevated more than twenty feet above the sea, so that storm-waves sometimes sweep completely over them. In I 847 such a wave destroyed Iooo of the small population, and there have been equally disastrous cyclones in much more recent times. Indeed, according to Hunter's Imperial Gazetteer of India, the islands, which have an area of two to three square miles, are nowhere more than ten or fifteen feet above the level of the sea. In $187 \mathrm{I}$ the population was estimated at about I 3,500 , and the almost sole cultivation is the coco-nut palm. It is supposed that the abundance of this palm may have attracted the first settlers, but as that event occurred more than 350 years ago-how much more it is impossible to say---this point must remain uncertain. The total annual value of the exports, consisting almost entirely of the products of the coco-nut palm, is said to be about $£ 17,000$. From the physical character of the group, it was not expected that the flora contained any endemic element, but until quite recently there was no published account of the vegetation, beyond broad generalizations. Dr. D. Prain, Curator of the Calcutta Herbarium, has supplied the want in the "Memoirs by Medical Officers of the Army of India," Part V., where he gives an enumeration and analysis of all the plants hitberto known by him to have been collected in the islands, and he has since communicated to the writer a list of some twenty additional species. Briefly, the vegetation consists, apart from cultivation, of very widely dispersed plants--whose wide area is due to ocean currents, birds, or winds-plus a number of weeds of NO. IO83, VOL. 42$]$ tropical cultivation. Dr. Prain has not visited any of the islands himself, and collectors have not concerned themselves with the question of colonization of plants from drift-seeds or from seeds conveyed to the islands by carpophagous birds; hence his deductions are mainly based on probabilities, which he discusses in considerable detail, followed by a table giving the full distribution of all the plants then known to him from the islands. These number eighty, including seventeen purely cultivated plants. It is interesting to know what is cultivated, of course; but it is undesirable to encumber the distributional tables with plants of this category. Dr. Prain estimates that the presence of eleven species is certainly due to the sea, seventeen probably so, and twenty-two possibly so; whilst birds are regarded as the agents in two, three, and five instances respectively. The two ferns collected in the island of Anderut are set down with certainty to the wind, and two or three other plants probably to the same agency. The rarity of ferns seems to be accounted for, in part at least, by the extreme flatness of the islands rather than by unfavourable conditions, for Dr. Treub found eleven species of ferns on the elevated part of Krakatã only three years after the great eruption, which absolutely destroyed all the vegetation previously existing, and covered the island with a volcanic deposit of intense heat from one to sixty yards in thickness.

One common tree in the vegetation of many islands of the Indian Ocean we miss in Dr. Prain's list, and that is Cordia subcordata, the iron-wood of the Keeling Islands.

\section{THE KURILES.}

Mr. Kingo Miyabe, lately appointed Professor of Botany at the Agricultural College, Sapporo, Japan, and formerly a student at Harvard, U.S., and for a short time in this country, is the author of a "Flora of the Kurile Islands," which is published in the Memoirs of the Boston [U.S.] Society of Natural History, vol. iv., No. 7 . 
This is perhaps the most finished piece of systematic and geographical botany yet published in English by a Japanese botanist, and it will give the author a reputation for completeness and conciseness that might be envied by many western botanists. The enumeration is based partly on personal observation and partly on scattered records and herbarium specimens, for which full references are given ; and all authorities are cited, so that the sources of information are not uncertain, as is too often the case.

The Kurile Islands form a chain nearly 800 miles long, extending from the southern point of Kamtschatka to Yezo; and, by treaty with Russia in 1875 , they are now all under Japanese rule. The principal islands are about twenty-four in number, but they are only partly inhabited, on account of their barrenness and lack of good water. The whole chain is described as of volcanic origin, and fifty-two cones have been observed, seventeen of which were active. The coasts generally are precipitous and unapproachable, and the few bays and coves they possess are insufficiently sheltered to be safe for ships in bad weather. Indeed, some of the islands can only be visited in the perfectly calm weather of the summer-time. In consequence of the sea-currents from the north, the climate is very cold for the latitude (about $43^{\circ}$ to $51^{\circ}$ ), and dense fogs prevail during easterly or southerly winds. There is, however, a marked difference in the climate of two or three of the southern islands, which come under the influence of a warm current running to the northeast. North of Etorofu the islands are locked in ice from November till April or May, and the mountains are snow-capped throughout the summer; hence it is not surprising to learn that the vegetation is of a sub-arctic character.

Mr. Miyabe's enumeration comprises 299 species of flowering plants, and I 8 vascular cryptogams; but it is not supposed that these numbers exhaust the flora. These 3 I 7 species belong to 187 genera and 53 natural orders, and 21 of the latter are represented by a single genus, and 9 by a single species each. The natural orders comparatively rich in genera are : Compositæ, I 5 ; Rosaceæ and Liliaceæ, I2; Gramineæ, I I Ranunculaceæ and Ericaceæ, 8; Cruciferæ and Umbelliferæ, 7 ; and most of these orders are the richest in species, though the Caryophyllaceæ and Scrophulariaceæ come in before the Cruciferæ and Umbelliferæ. The Compositæ number 30 species; the Rosaceæ, 23 ; the Gramineæ, 17 ; and the Ericaceæ, 16. It is noteworthy that in this small flora, or, rather, portion of a flora, the Compositæ form a relatively high percentage, as they do in the Arctic flora and in the various regions of Central and Eastern Asia, from the Caspian to Japan, whose floras have been analyzed by Maximowicz. So far as at present known, the Kurile flora contains no endemic element, unless we except two imperfectly-known plants, which, however, as Mr. Miyabe observes, are much more likely to be forms of more widely-spread species. North of the islands mentioned as under the influence of a warm sea-current, the flora is largely composed of species having a wider range, many of them all round the northern hemisphere, and species having a more or less wide area in North-East Asia. The facts that upwards of 25 per cent. of the species are British, and that 84 per cent. of the genera are spread over Europe, Northern Asia, and North America, will assist us in forming an idea of the general composition of the vegetation. Only three of the genera are restricted to the mountains of tropical Asia and North-Eastern Asia-namely, Skimmia, Crawfurdia, and Acanthopanax. Mr. Miyabe finds that 26 per cent. of the species are American-Asiatic; and Io per cent. of these reach Eastern North America. Only six genera occur which do not reach Japan-namely, Parrya, Tetrapoma, Claytonia, Lupinus, Armeria, and Dodecatheon.

NO. $\operatorname{IO}_{3}$, VOL. 42$]$
The existence in the southern islands, Kunashiri and Etorofu, of such plants as the following is strong evidence of a warmer climate: Dianthus superbus, Hypericum erectum, Skimmia japonica, Ilex crenata, Rhus Toxico. dendron, Hydrangea scandens, Aralia racemosa, Acanthopanax ricinifolia, Crazufurdia japonica, and Bambusa Kurilensis. The bamboo is said to grow so thick and so tall in the neighbourhood of Shana, in Etorofu, as to form almost impassable thickets.

Mr. Miyabe concludes his discussion of the flora of the Kuriles in the following words :- "From these observations I agree with Prof. Milne in the opinion that, at the time of the last great southerly migration of the rich polar flora, Japan received her portion mostly through the island of Saghalin, and but little, if any, through the then uncompleted chain of the Kurile Islands."

\section{The BAHAMAS.}

A provisional list of the plants of this chain of islands, by John Gardiner and L. J. K. Brace, edited by Prof. C. Dolley, appears in the Proceedings of the Academy of Natural Sciences, Philadelphia, 1889, pp. I3I-426.

This is not intended as a critical review, and perhaps an avowed provisional list is, in a sense, exempt from such an ordeal; yet it seems no more than right to call attention to the extraordinary notes and remarks under some of the species, genera, and orders, so that the writer who is responsible for them may have the opportunity of claiming all the credit due to him. Taking the first of the dicotyledons, Clematis Vitalba, it is said to be "indigenous and nearly cosmopolitan" ; and $\mathrm{Del}$ phinium sp. is recorded as "indigenous from old world," whatever that may mean. The Bixineæ, "as a whole, have fully bitter and astringent properties, and some of the members are poisonous." This is indefinite, but the Compositæ are described as "plants mostly possessing a bitter principle which renders them tonic"; and Eupatorium (a genus of about 500 species) "is extensively used as a remedy for malaria." A more definite statement, "grasses are valuable as food for cattle and men," is true, although the instances on record of men having eaten grass itself are exceedingly rare. Some of the remarks on the distribution of the plants enumerated, and really restricted to the West Indian region, or the West Indian and Mexican regions, are equally incomprehensible. Thus Alvaradoa amorphoides, a shrub inhabiting the Bahamas, Cuba, and Mexico, including the interior province of Chihuahua in the north, is said to be found on "all tropical coasts." The work abounds in indefinite, and often unintelligible, remarks on the medicinal properties of plants. Under Clethra tinifolia we find the note : "This plant does not appear to be of use for anything. The order [Ericaceæ] has astringent properties. Its leaves and flowers are used as a diaphoretic; they are saponaceous and detergent."

The list itself is largely compiled from Grisebach's "Flora of the British West Indies," and from names communicated from Kew to Mr. Brace, based on specimens supplied by him from time to time; and is so far approximately correct. On the other hand, some of the additional names are strangely inaccurate and far-fetched Thus, Sinapis Brassicata, Linn., a Chinese plant, now believed to be the same as $S$.juncea, is put down as mustard, and as native of the West Indies. It is true that Grisebach uses this name in his "Flora. of the British West Indian Islands," therefore it is, to that extent, excusable. That an "M.D." and a Professor of Biology should be so careless of his reputation as to publish such undigested matter is inconceivable. Apart from its faults, the list is imperfect so far as our present knowledge goes, and it may be better to await an emended edition before attempting to give any particulars of the flora here. 


\section{FERNANDO NORONHA.}

Darwin landed on this island on the outward voyage of the Bergle, and collected a few plants, and Moseley succeeded in obtaining specimens of a few plants from the main island and the islet of St. Michael's Mount, but was prevented from making a complete collection in consequence of the Challenger being unprovided with the necessary authorization. These plants were described by the writer, and some of them figured in the "Botany of the Challenger Expedition." Provided with funds by the Royal Society, Mr. H. N. Ridley, formerly of the British Museum, and now Government Botanist for the Straits Settlements, visited the island in the summer of 1887 , accompanied by Mr. G. A. Ramage and the Rev. T. S. Lea. The party remained on the island; or rather group, for there are several islets besides the main island, forming a chain, which may have formerly been continuous. Thus they had time to explore thoroughly the natural history ; and an account of the botany, by Ridley, has just appeared in the current volume of the Journal of the Linnean Society. The singularly unconnected form of the introductory matter is doubtless due to the hurried manner in which it had to be completed before the author's departure for Singapore.

Fernando Noronha is in about $3^{\circ} 50^{\prime} \mathrm{S}$. lat., and nearly 200 miles from the nearest point of the Brazilian coast. The whole chain is about eight miles in length, and the main island five miles long and nearly two miles across in one part, though very much narrower generally.

The fragment of the flora published in the "Botany of the Challenger" was considered sufficient to enable us to form an opinion of its general character, and state that there was no peculiarly insular element in the vegetation. This is fully borne out by the subsequent discoveries.

Mr. Ridley gives no analysis of the composition of the flora beyond classifying the plants as weeds, such plants as might be introduced by sea-currents, and such as have berries and eatable seeds, with examples; but he does not tabulate the whole. His very brief "summary" follows :-

"The whole group of islands possesses certain characteristics common to all truly oceanic islands and some of those which are merely the relics of vanished continents. In the first place there is the absence of indigenous mammals, and more noticeably of bats, of fresh-water fish, and amphibians. Again, the number of indigenous species, both of plants and animals, is very small, while the number of individuals is very large. The insects are small and dull in colour, and but few of the plants have showy flowers, white and yellow being prevailing colours. A considerable proportion of the indigenous plants are shrubby or arboreous, as in many other oceanic islands; but arboreous or even shrubby Compositæ do not exist, indigenous species of the order being rare in the group."

There will be differences of opinion, of course, as to the teachings of the data collected by $\mathrm{Mr}$. Ridley and his companions, especially as to whether the present vegetation be a remnant of a former continental flora. or a purely derived insular flora of comparatively recent origin.

Mr. Ridley himself states "that there is no evidence whatever to show a former connection with the mainland of Brazil at any time, in spite of what has been asserted by Dr. Rattray to the contrary." On the other hand, in a sketch of the geology of the island, based on petrological notes by Thomas Davies, which follows the enumeration, it is merely doubted" "that the evidence is sufficient to prove a connection."

It appears, too, that "some American petrologists, who have found similar rocks to those of Fernando Noronha in the neighbourhood of Cape San Roque, seem to consider that the group may have been connected at one time with the mainland at this point."

Roughly counting the plants in the enumeration, we NO. IO8 3 , VOL. 42$]$ find there are nearly two hundred species of phanerogams, including weeds and a few others undoubtedly introduced, intentionally or unintentionally, by man. Out of this total, about thirty-two are described as new, or, in about half-a-dozen instances, more fully described than was possible from the imperfect material previously known. So far as present evidence goes, these are all endemic in Fernando Noronha; but while so much remains to be done in the investigation of the Brazilian flora, it should not be assumed that they are really so. Some of them, indeed, are admittedly very closely allied to previously-described species, and botanists might differ as to the propriety or expediency of treating the majority of them as independent species. And as to the whole, they present no peculiar characteristic suggesting the improbability of their occurring on the mainland.

The poverty of the flora in species may be largely due to climatal and other conditions. The climate is so dry generally, or the periods of drought are so protracted, that marsh plants, epiphytes, and ferns are almost wholly wanting. Mr. Ridley discovered one fern, Pellaca geraniafolia, but it was rare and local, and this very widelyspread fern will grow in comparatively dry situations.

A large number of the plants, including several of the supposed endemic species, bear edible fruits; yet "there is only one fruit-eating bird on the island, and that is the endemic dove, Zenaida noronhe." This fact tempts Mr. Ridley "to wonder whether the number of endemic species with edible fruit could possibly have all been introduced by this single species of dove, or whether other frugivorous birds may not at times have wandered to the shores." This sentence can hardly convey what Mr. Ridley had in his mind when he wrote; and being so distant from home he probably had no opportunity of revising it in print. Moreover, it is hardly correct to designate this group of islands as "oceanic."

Prominent in the vegetation among the assumed new or endemic plants are: Erythrina aurantiaca, Cereus insularis, Bignonia roseo-alba, Pisonia Darwinii, Sapium sceleratum, and Ficus noronhee. There are also described two species of Oxalis, three of Ceratosanthes, a genus of Cucurbitaceæ, a Sesuvium, a Cuscuta, a Physalis, a Solanum, a Lantana, and three of Cyperus, besides a few others of less familiar genera. Of greater botanical interest is an apparently diœcious Combretacea, provisionally placed in Combretum as the type of a new section, Terminaliopsis. Taken as a whole, the vegetation is quite that of the mainland deprived of the moisture-loving element.

In conclusion, it may be stated that the woods mentioned by the earlier writers have almost disappeared since the main island has been made a convict settlement. W. BOTTING HEMSLEY.

\section{THE BRONTOMETER.}

FOR more than a century meteorologists have been puzzled by the exceptional action of the barometer during some (not all) thunderstorms, and during some (but not all) heavy rains. As a general rule, one expects the barometer to fall for rain and bad weather, but in 1784 Rosenthal pointed out that "when a thunderstorm approaches the place where a barometer is situated, the mercury in the tube begins to rise ; the nearer the thundercloud comes to the zenith of the observer, the higher does the mercury rise, and reaches its highest point when the storm is at the least distance from the observer. As soon, however, as the cloud has passed the zenith, or has become more distant from the observer, the weight of the atmosphere begins to decrease and the mercury to fall."

The recent rapid increase in the number of self-recording barometers in use has led to much interest being taken in these fluctuations, which are sometimes very 